\title{
Carta editorial do número temático sobre cultura
}

Este número da Revista Horizontes de Lingüística Aplicada é temático, centrando-se em cultura. Apresentamos, com muito prazer, dez artigos: seis relacionados a atividades que podem ser desenvolvidas em sala de aula para lidar com aspectos culturais; um sobre a abordagem cultural de professores; um lidando com o letramento e identidade do professor; um enfocando o desentendimento entre falantes de línguas diferentes; e, por fim, um relatando a tradução de marcadores culturais em um texto à luz da lingüística de corpus.

No primeiro artigo "Roteiros culturais: modelo teórico na abordagem de conteúdos socioculturais no ensino/aprendizagem de línguas estrangeiras”, os co-autores Alba Escalante e Enrique Huelva Unternbäumen, da Universidade de Brasília, apresentam o “modelo teórico dos roteiros culturais". Fundamentados em Wierzbicka, trazem exemplos de roteiros culturais, "fazendo um recorte de uma pesquisa onde foram levantados e comparados alguns traços do roteiro da negação em falantes de língua espanhola de diversas áreas geolectais e em falantes do português do Brasil”. Também fazem propostas de como aplicar os roteiros culturais "para o tratamento dos conteúdos socioculturais no ensino/aprendizagem de língua estrangeira”.

Dilys Karen Rees e Flávia Iolanda Simas Kumar, da Universidade Federal de Goiás, no segundo artigo "A análise de uma aula de conversação em LE inglês: o uso de um tema polêmico" analisam uma aula de língua inglesa onde foi apresentado "um tema polêmico, 'Begging', do livro, Taboos and Issues, como base da discussão desenvolvida em sala de aula". Levantaram os "domínios culturais que os autores do livro didático, do qual o tema foi retirado, usam para defender o uso de temas polêmicos em sala”. Depois analisaram as "afirmações dos alunos sobre o assunto" através do "levantamento dos domínios culturais". Mostram a "complexidade dos discursos que fluem em sala de aula e as rupturas que ocorrem" e discutem a importância do "professor estar preparado para lidar com estes momentos".

No terceiro artigo, "Discurso e cultura na aula de língua materna: uma abordagem discursiva da textualidade”, Luciana Cristina Ferreira Dias, da Universidade Estadual do Centro-Oeste (Guarapava, Paraná), aborda a "problemática acerca da linguagem e da identidade nos estudos de perspectiva discursiva, de Pêcheux e de Orlandi”. No artigo, ela "analisa representações construídas discursivamente sobre o Brasil, compreendendo os sentidos produzidos em práticas de leitura em língua materna”. A base teórica é a "Proposta Multidimensional-Discursiva, de Serrani, que considera a interdependência entre três componentes: o intercultural, língua e discurso e práticas verbais”. Ela analisou os resultados do uso de um texto de Marilena Chauí, em sala de aula, observando que a “cultura brasileira e a estrutura da língua podem ser trabalhadas de maneira integrada”. Ressalta que "a articulação do componente sociocultural ao língua-discurso nos fornece uma chance de compreender o funcionamento discursivo de textos sobre cultura”.

Lucrécio Araújo de Sá Júnior e Beliza Áurea de Arruda Mello, da Universidade Federal da Paraíba, no quarto artigo, trazem a sugestão em "Etnografia e letramento: novos desafios para velhas memórias" de usar "tradições orais para o processo de letramento" de adultos. A base teórica se centra em "estudos de letramento para ilustrar o poder da etnografia como 
experiência contextualizada”. Concluem que “os aspectos da cultura oral que se mantêm em uma sociedade podem ser concebidos em torno das origens, necessidades e interesses dos alunos e podem incentivar uma "dialógica” onde os alunos sejam capazes de utilizar a alfabetização desenvolvendo habilidades para analisar criticamente o seu lugar na sociedade e compreender como certas pressuposições e percepções culturais têm afetado a eles e suas famílias".

No quinto artigo, “Jokes and riddles in the English as a foreign language classroom”, Lélia Silveira Melo Souza, da Universidade de São Paulo, relata a experiência de usar piadas na sala de aula para o ensino/aprendizagem de inglês como língua estrangeira. Ela centraliza seu estudo "sob seis aspectos que contribuem para uma melhor compreensão, pelos alunos, de piadas: interpretação, estrutura, ferramenta de aprendizagem, questões culturais, diferenças individuais e motivação". Ela escreve que, quanto a fatores culturais, "muitas vezes as piadas representam uma transgressão cultural, que os alunos precisariam entender para compreenderem a piada". Ela afirma que os resultados foram positivos, pois o "uso de piadas foi fator de motivação entre os alunos para a aprendizagem de cultura e língua estrangeira".

Ana Graça Canan, da Universidade Federal do Rio Grande do Norte, no sexto artigo "Great Expectations em aula de língua inglesa”, escreve sobre o "desenvolvimento de atividades para a utilização do romance Great Expectations de Charles Dickens, na perspectiva da cultura, na sala de aula de língua inglesa”. Identificou o "discurso da cultura urbana” como sendo o "mais recorrente na obra", selecionou fragmentos específicos da obra e desenvolveu as atividades em cima destes. Aponta que o mesmo processo "pode ser aplicado a outros textos literários também, assim produzindo atividades para serem utilizados dentro da perspectiva cultural”.

O sétimo artigo "Visão e abordagem cultural de professores em sala de aula de LE (inglês) e os PCNs”, de Oldinê Ribeiro de França e Cynthia Ann Bell dos Santos, da Universidade de Brasília, relatam "um estudo cujo objetivo foi identificar a visão de professores de língua estrangeira - LE (inglês) sobre o ensino de cultura e a abordagem cultural adotada em sala de aula, especialmente se espaços interculturais eram criados, como apregoam os documentos oficiais, a saber, os Parâmetros Curriculares Nacionais (PCNs), que orientam o Ensino Fundamental e Médio no Brasil”. Entre outros, os resultados indicaram que "os professores não enfocam profundamente espaços interculturais tão importantes e necessários para preparar o aprendiz para viver no mundo contemporâneo, conforme explicitam os PCNs".

Ana Lúcia de Campos Almeida, da Universidade Vale do Rio Verde (Três Corações, Minas Gerais), no oitavo artigo "O letramento do professor, sua relação com a identidade profissional docente e com a formação de novos leitores”, apresenta as "práticas de letramento do sujeito-professor", e analisa a "relação que se estabelece entre a construção de sua identidade enquanto leitor e enquanto profissional docente, envolvido na formação de novos leitores”. Os resultados apontaram "a existência de significativa relação entre as práticas de letramento do professor e a constituição de uma identidade profissional empoderada, refletida na atuação do sujeito-professor como um agente de letramento”. 
O nono artigo "Reflexões sobre o desentendimento entre línguas", de Simone Hashiguti, da Universidade Estadual de Campinas, reflete sobre o "desentendimento nas relações interpessoais entre falantes de diferentes línguas por uma perspectiva discursiva de linguagem”. Analisa um filme, Furyo: em nome da honra, "outros fragmentos de textos: relatos de imigrantes (e de seus descendentes ou parentes) e de alunos de línguas estrangeiras sobre situações de desentendimento”. Chega à conclusão que, “na relação entre línguas, os desentendimentos se referem ao historicamente (interdiscursivamente) possível para cada língua”.

Por fim, no décimo artigo "A tradução de marcadores culturais em Sargento Getúlio à luz da lingüística de corpus”, Elisangela Fernandes Martins e Diva Cardoso de Camargo, da Universidade Estadual Paulista, analisam a "tradução de marcadores culturais em Sergeant Getulio em relação ao seu original Sargento Getúlio, ambos do escritor e autotradutor João Ubaldo Ribeiro" através de lingüística de corpus, estudos da tradução baseados em corpus, domínios culturais e modalidades tradutórias. Os resultados indicam que "João Ubaldo Ribeiro busca uma maior aproximação entre o leitor de língua inglesa e a mensagem do original por meio do uso de recursos da modulação, da explicitação e da adaptação ao traduzir, para o inglês, marcadores culturais específicos da realidade brasileira”.

Gostaríamos de agradecer ao co-organizador Enrique Huelva Unternbäumen e aos pareceristas e autores que contribuíram para este número com seu tempo, conhecimento, sabedoria e boa fé. Agradecemos também o trabalho meticuloso da revisora Micla Cardoso de Souza e a editoração eletrônica profissional de Washington Ribeiro, Socorro Lima e Bruno Vieira, que contribuíram para a qualidade desta Revista. Esperamos que os artigos aqui incluídos levem aos leitores informações interessantes e aplicáveis nas suas áreas de atuação, quanto ao fator cultural que está sempre presente.

Saudações,

\section{Cynthia Ann Bell dos Santos}

